\title{
Association between Maternal Age at Pregnancy, Socioeconomic Status, Physical Environment, Prenatal, Perinatal, Postnatal History, and the Risk of Mental Retardation
}

\author{
Erna Nurochim', Dono Indarto'), Adi Prayitno²) \\ 1) Masters Program in Public Health, Universitas Sebelas Maret \\ 2) Faculty of Medicine, Universitas Sebelas Maret
}

\begin{abstract}
Background: Mental retardation (MR) is a serious public health problem for a country. The prevalence of mental retardation in Indonesia was estimated at 1-3\% of the population. About $0.1 \%$ of which need treatment and guidance the whole life. This study aimed to determine the association between maternal age at pregnancy, socioeconomic status, physical environment, prenatal, perinatal, postnatal history, and mental retardation.

Subjects and method: This was an analytic observational study with case control design. This study was conducted in Pare, Kediri, East Java, Indonesia, from October to December 2016. A total 105 study subjects, consisting of 35 MR cases and 70 controls were selected for this study by fixed disease sampling. The independent variables were maternal age at pregnancy, socioeconomic status, physical environment, prenatal, perinatal, and postnatal history. The dependent variable was mental retardation. The data were collected by questionnaire and analyzed by logistic regression model.

Results: Maternal age $\geq 35$ years at pregnancy was associated with an increased risk of MR, and it was statistically significant The result showed that mother's age while pregnant $(\mathrm{OR}=10.18 ; 95 \% \mathrm{CI}=$ 2.77 to $37.39 ; \mathrm{p}<0.001)$. High socioeconomic status $(\mathrm{OR}=0.23 ; 95 \% \mathrm{CI}=0.07$ to $0.81 ; \mathrm{p}=0.022)$, good physical environment $(\mathrm{OR}=0.13 ; 95 \% \mathrm{CI}=0.04$ to $0.45 ; \mathrm{p}=<0.001)$, good prenatal history $(\mathrm{OR}=0.24 ; 95 \% \mathrm{CI}=0.07$ to $0.82 ; \mathrm{p}=0.022)$, good perinatal history $(\mathrm{OR}=0.45 ; 95 \% \mathrm{CI}=0.15$ to $1.40 ; \mathrm{p}=0.168)$, good postnatal $(\mathrm{OR}=0.43 ; 95 \% \mathrm{CI}=0.14$ to $1.35 ; \mathrm{p}=0.148)$, were associated with a decreased risk of MR. Nagelkerke $\mathrm{R}^{2}=53.8 \%$ for this model.
\end{abstract}

Conclusion: Maternal age $\geq 35$ years at pregnancy increases the risk of MR. High socioeconomic status, good physical environment, good prenatal, perinatal, and postnatal history, decrease the risk of MR.

Keywords: mental retardation, maternal age at pregnancy, socioeconomic status, environment, pregnancy history.

\section{Correspondence:}

Erna Nurochim. Masters Program in Public Health, Universitas Sebelas Maret, Jl. Ir. Sutami 36A, Surakarta, Central Java, 57126. Email:

\section{BACKGROUND}

$\overline{\text { Mental retardation is a serious public health }}$ problem for a country. The prevalence of mental retardation is a world problem that has a major impact, especially for developing countries. Nations whose citizens are suffering from mental retardation will experience weaknesses in terms of competitiveness with other nations, thus mental retardation needs to be known, avoided and overcome.
Estimates of severe mental retardation cases accounted for about $0.3 \%$ of the population and almost $3 \%$ has an IQ below 70. This will certainly complicate the condition of children because $0.1 \%$ of these children require care, guidance, and supervision throughout their lives (UNICEF, 2013).

Mental retardation is a state of normal intelligence development from birth or childhood with an IQ of less than 70, which is 
associated with limitations in cognitive function and adaptive behavior (Dalami et al., 2013; Huang, 2016; Al-Amri et al., 2016). The prevalence of mentally retarded people is not known for certain, but the figure is estimated at $1-3 \%$ of the entire human population (Dwi et al., 2016). Other study in the Netherlands reported based on the meta-analysis population, it revealed a prevalence of $1 \%$ mental retardation with $85 \%$ of all cases being mild retardation, moderate mental retardation of $10 \%$ and severe $5 \%$ weight retardation (Iqbal and Bokhoven, 2014).

The cause of mental retardation or intellectual disability is very heterogeneous, due to genetic and non-genetic factors. Chromosomal abnormalities and single gene abnormalities are included in the genetic factors. Non-genetic factors include maternal age at pregnancy, socioeconomic status, environment, prenatal, perinatal and postnatal history (Huang et al., 2016; Iqbal and Bokhoven, 2014).

Pregnancy in older women especially after 35 years has a risk of giving birth to a child with mental retardation because the mother also has accompanying disease. Socioeconomic is anything related to the fulfillment of the needs of society, such as clothing, food, housing, education, health, and others. The socioeconomic status of the family may affect the occurrence of mental retardation in children (UNICEF, 2013; Nisbett et al., 2012).

Other study say mothers who come from families with low socioeconomic status tend to be inadequate for good nutritional needs for the fetus. As a result, the babies born have low weight and short body length and tend to experience malnutrition. Thus, the development of children is disturbed (Irianto, 2014).
Prenatal periods contribute to maternal and fetal mortality and morbidity, including neurological disorders, growth and mental development of children. Ten prenatal factors (maternal age, black race, low education, high parity, consuming alcohol, smoking, had diabetes mellitus, hypertension, maternal epilepsy, or asthma) may increase the incidence of MR (Huang et al., 2016).

Perinatal periods that are experiencing difficulties during childbirth (old partus, childbirth with actions that result in trauma to newborns, dystocia, prematurity, premature abnormalities and poor postnatal history, nutrition, stimulation, parental protection, and culture will risk children experiencing mental retardation (Irianto, 2014).

Environmental factors can affect mental development, such as emotional or physical neglect. Stimulation is very important for child development. When children are neglected, such as not getting enough nutrition, their brain development can be disrupted (AAIDD, 2010). Therefore, the study wanted to prove the above concept by doing study about maternal age, socioeconomic, environmental factors, prenatal, perinatal, and postnatal history with mental retardation.

This study aimed to analyzed the relationship of maternal age at pregnancy, socioeconomic, environment, prenatal, perinatal, postnatal history, and the incidence of mental retardation.

\section{SUBJECTS AND METHOD}

\section{Study Design}

This was an analytic observasional study with case control approach. This study was conducted in Pare, Kediri, East Java, from October to December 2016.

\section{Population and Sample}

A total 105 study subjects was selected for this study by fixed disease sampling with a 
ratio of 1:2 for case and control groups. Data were collected using questionnaires.

\section{Study Variables}

The dependent variable was mental retardation. The independent variables were maternal age at pregnancy, socioeconomic, physical environment, prenatal, perinatal, and postnatal history.

\section{Data Analysis}

The data were analyzed by a multiple logistic regression run on SPSS 20 program.

\begin{tabular}{l}
\hline RESULTS \\
\hline 1. Characteristics of study subjects \\
Characteristics of study subjects of parents \\
(father and mother) based on maternal age, \\
socioeconomic which includes education, \\
employment, and family income can be seen \\
in Table 1. A total of 57 mothers ( $54.3 \%$ ) of \\
the case and control group were women who \\
were not at high risk and the number of \\
women at high risk was 48 mothers ( $45 \cdot 7 \%$ ). \\
Most of the education level of parents \\
(father and mother) in case and control \\
group was $\geq$ senior high school.
\end{tabular}

\section{RESULTS}

1. Characteristics of study subjects

Characteristics of study subjects of parents (father and mother) based on maternal age, socioeconomic which includes education, employment, and family income can be seen in Table 1. A total of 57 mothers (54.3\%) of the case and control group were women who were not at high risk and the number of women at high risk was 48 mothers (45.7\%). Most of the education level of parents (father and mother) in case and control group was $\geq$ senior high school.

Table 1. Parental Characteristics

\begin{tabular}{lcc}
\hline \multicolumn{1}{c}{ Parents Characteristics } & $\mathbf{N}$ & \% \\
\hline Maternal Age (year) & & 54.3 \\
$20-34$ & 40 & 38.1 \\
$35-40$ & 8 & 7.6 \\
<40 & 11 & 10.5 \\
Maternal Education & 25 & 23.8 \\
Primary School & 49 & 46.7 \\
Middle School & 20 & 19 \\
Senior High School & & \\
College & 67 & 63.8 \\
Maternal Job & 6 & 5.7 \\
House wife & 8 & 7.6 \\
Farmworker & 24 & 22.9 \\
Civil Servant & & \\
Private worker/farmer & 27 & 25.7 \\
Family Income & 78 & 74.3 \\
< Rp 1,456,ooo & & \\
R Rp 1,456,ooo & 14 & 13.3 \\
Paternal Education & 17 & 16.1 \\
Primary School & 40 & 38.2 \\
Middle School & 34 & 32.4 \\
Senior High School & & \\
College & 20 & 19.1 \\
Paternal Occupation & 6 & $5 \cdot 7$ \\
Jobless & 8 & 7.6 \\
Farmworker & 71 & 67.6 \\
Civil employees & & \\
Private worker/farmer & & \\
\hline & &
\end{tabular}

Most of the employment status of the mother was housewife (67 people), and working father (85 people). Based on interviews, there were 20 fathers who did not work and still earned income from renting agricultural land. Fathers who did not have jobs due to illness, helped their wives business venture (delivering merchandise to the buyer), and cleaned up the gardens although not every day. 
Journal of Maternal and Child Health (2016), 1(2): 119-130

https://doi.org/10.26911/thejmch.2016.01.02.02

Characteristics of children in case and control groups based on birth status, child age, gender, birth order, infant weight at birth and causation of children with mental retardation. The results of the characteristics of the study subjects are shown in Table 2. Description of study variables was described by characteristics, criteria, frequency and percentage.
All study subjects were born from parents who had no relationship of inbreeding. The study subject between cases and controls had similar characteristics except for age and birth order of the child. The age of the study subjects of case group was more at the age of 6-11 years, while the control group was more in the age range $\geq 12$ years.

Table 2. Characteristics of study subject

\begin{tabular}{|c|c|c|c|c|}
\hline \multirow{2}{*}{ Children Characteristics } & \multicolumn{2}{|c|}{ MR } & \multicolumn{2}{|c|}{ No MR } \\
\hline & $\mathbf{n}$ & \% & $\mathbf{n}$ & \% \\
\hline \multicolumn{5}{|l|}{ Consanguineous marriage } \\
\hline Children from consanguineous marriage & 35 & $33 \cdot 3$ & 70 & 66.67 \\
\hline \multicolumn{5}{|l|}{ Age of children case and control group } \\
\hline $0-5$ уо & 2 & 1.91 & - & 0 \\
\hline 5-11 yo & 15 & 14.28 & 28 & 26.67 \\
\hline$\geq 12$ yo & 18 & 17.14 & 42 & 40 \\
\hline \multicolumn{5}{|l|}{ Gender } \\
\hline Male & 17 & 16.19 & 33 & 31.43 \\
\hline Female & 18 & 17.14 & 37 & 35.24 \\
\hline \multicolumn{5}{|l|}{ Birth order } \\
\hline First child until second & 14 & 13.33 & 51 & 48.57 \\
\hline Third child and so on & 21 & 20 & 19 & 18.09 \\
\hline \multicolumn{5}{|l|}{ The baby's weight at birth } \\
\hline$\leq 2,500$ gram & 13 & 12.38 & 7 & 6.66 \\
\hline$\geq 2,500-4,000$ gram & 22 & 20.95 & 63 & 60 \\
\hline \multicolumn{5}{|l|}{ Cause of mental retardation } \\
\hline Down Syndrome & 23 & 21.91 & 0 & o \\
\hline Not Down Syndrome/ IQ $<70$ & 12 & 11.43 & 70 & 66.67 \\
\hline
\end{tabular}

There was a meaningful relationship with the children birth order of the study subjects between case and control group. Children with MR were more common in the order of the 3rd child and so on. That was 21 children. Whereas in the case group, more children with MR were born on the order of the 1st and 2nd. That was 51 children. The baby's weight at birth between case and control groups showed that both groups were commonly with normal weight, ranging from 2,500 grams to 4,000 grams. The cause of MR in the case group indicated that the MR child is more due to down syndrome. They were 23 children.

\section{Bivariate Analysis}

Variables in the study were maternal age at pregnancy, socioeconomic, environmental, prenatal, perinatal and postnatal history with MR incidence. The method used was chi-square test.

The result of bivariate analysis showed that maternal age at no risk ( $<35$ years) would reduce the incidence of 0.20 times higher compared with the age of the mothers at risk ( $\geq 35$ years). Higher social economy would reduce the incidence of MR o.30 times higher than the non-risk environment $(\geq 28.52)$ would reduce the incidence of MR 0.33 times higher than the risky environment.

A non-risk prenatal history $(\geq 16.04)$ would decrease the incidence of MR by 0.30 times higher than with a prenatal history at risk. A non-risk perinatal history would decrease the incidence of MR 3.30 higher than 
with a non-risk perinatal history. A non-risk postnatal history $(\geq 10.63)$ would decrease Table 3. Bivariate analysis with Chi square the incidence of mental retardation by 0.20 higher than with a risky postnatal history.

\begin{tabular}{|c|c|c|c|c|c|c|c|c|}
\hline \multirow[t]{2}{*}{ Variable } & \multicolumn{4}{|c|}{$\begin{array}{l}\text { Categories of mental } \\
\text { retardation }\end{array}$} & \multirow[t]{2}{*}{ Total } & \multirow[t]{2}{*}{$\%$} & \multirow[t]{2}{*}{$\mathbf{O R}$} & \multirow[t]{2}{*}{$\mathbf{p}$} \\
\hline & Yes & $\%$ & No & $\%$ & & & & \\
\hline Maternal age at pregnancy & & & & & & & 0.20 & $<0.001$ \\
\hline$\geq 35$ years & 25 & 71.4 & 23 & 32.9 & 48 & $45 \cdot 7$ & & \\
\hline$<35$ years & 10 & 28.6 & 47 & 67.1 & 57 & $54 \cdot 3$ & & \\
\hline Socioeconomic Status & & & & & & & 0.30 & 0.006 \\
\hline High (score $\geq 3.2$ ) & 10 & 28.6 & 40 & 57.1 & 50 & 47.6 & & \\
\hline Low (score <3.2) & 25 & 71.4 & 30 & 42.9 & 55 & 52.4 & & \\
\hline Physical Environment & & & & & & & 0.33 & 0.008 \\
\hline Poor $($ score $<28.52$ ) & 21 & 59.9 & 23 & 32.9 & 44 & 41.9 & & \\
\hline Good (score $\geq 28.52)$ & 14 & 40.1 & 47 & 67.1 & 61 & 58.1 & & \\
\hline Prenatal Hisory & & & & & & & 0.30 & 0.007 \\
\hline Poor $($ score < 16.04) & 28 & 79.9 & 37 & 52.9 & 65 & 61.9 & & \\
\hline Good (score $\geq 16.04)$ & 7 & 20.1 & 33 & 47.1 & 40 & 38.1 & & \\
\hline Perinatal History & & & & & & & 3.30 & 0.006 \\
\hline Poor $($ score < 11.66) & 25 & 71.4 & 30 & 42.9 & 55 & 52.4 & & \\
\hline Good (score $\geq 11.66$ ) & 10 & 28.6 & 40 & 57.1 & 50 & 47.6 & & \\
\hline Postnatal History & & & & & & & 0.20 & $<0.001$ \\
\hline Poor (score <10.63) & 24 & 68.6 & 19 & 27.1 & 43 & 40.9 & & \\
\hline Good (score $\geq 10.63$ ) & 11 & 31.4 & 51 & 72.9 & 62 & 59.1 & & \\
\hline
\end{tabular}

\section{Logistic Regression Analysis}

The results of logistic regression analysis showed that there was a negative and significant relationship between maternal age to the risk of children experiencing mental retardation. Children born to pregnant women aged $<35$ years had a risk of mental retardation 10.18 times lower than children born to mothers aged $\geq 35$ years $(\mathrm{OR}=0.10 ; 95 \% \mathrm{CI}=$ 0.03 to 0.36 ; $\mathrm{p}<0.001)$.

Table 4. Logistic regression analysis of risk factors for mental retardation

\begin{tabular}{lcccc}
\hline \multicolumn{1}{c}{ Variable } & \multirow{2}{*}{ OR } & \multicolumn{2}{c}{ 95\%CI } & \multirow{2}{*}{ p } \\
\cline { 3 - 4 } & & Lower limit & Upper limit & \\
\hline Maternal age at pregnancy $\geq 35$ year & 10.18 & 2.77 & 37.39 & $<0.001$ \\
High Socioecomic & 0.23 & 0.07 & 0.81 & 0.022 \\
Good prenatal history (score $\geq 16.04)$ & 0.24 & 0.07 & 0.82 & 0.022 \\
Good perinatal history (score $\geq 11.66)$ & 0.45 & 0.15 & 1.40 & 0.168 \\
Good postnatal history (score $\geq 10.63)$ & 0.43 & 0.14 & 1.35 & 0.148 \\
Good physical environment (score $\geq 28.52)$ & 0.13 & 0.04 & 0.45 & $<0.001$ \\
N Observation & 105 & & & \\
-2 Log likelihood & 82.169 & & & \\
Nagelkerke R ${ }^{2}$ & $53.8 \%$ & & & \\
\hline
\end{tabular}

There was a negative and significant relationship between the socioeconomic parent and the risk of the child experiencing mental retardation. Children born from a high-socioeconomic parent had a quarter lower risk of mental retardation than children with low socioeconomic parents $(\mathrm{OR}=$ $0.23 ; 95 \% \mathrm{CI}=0.07$ to $0.81 ; \mathrm{p}=0.022$ ). 
Journal of Maternal and Child Health (2016), 1(2): 119-130

https://doi.org/10.26911/thejmch.2016.01.02.02

There was a negative and significant relationship between the environment and the child's risk of experiencing mental retardation. Children who were born and raised in a good physical environment, had one eighth mental retardation lower than children who were born and lived in an environment that was not good $(\mathrm{OR}=0.13$; $95 \% \mathrm{CI}=0.04$ to $0.45 ; \mathrm{p}<0.001$ ).

There was a negative and significant relationship between prenatal history with a child's risk for experiencing MR. Children born from mothers who gained well with ANC would lose 0.24 times lower than children born from mothers whose gestation did not receive good ANC (OR= 0.24; 95\% $\mathrm{CI}=0.07$ to $0.82 ; \mathrm{p}=0.022$ ).

There was a negative relationship between perinatal history and the risk of a child to have an MR although not statistically significant. Children born safely during the birth process and able to adapt to the environment outside the womb were able to reduce the risk of children having MR 0.45 times lower than those in children who experienced complications in the perinatal period, $(\mathrm{OR}=0.45 ; 95 \% \mathrm{CI}=0.15$ up to $1.40 ; \mathrm{p}=0.168$ ).

There was a negative relationship between postnatal history with a child's risk for experiencing MR although it was not statistically significant. Children who had good body resistance during infancy, children and adolescents and were able to pass the stage of growth and development according to the age of children, could reduce the risk of children experiencing mental retardation 0.43 times lower than in children who are susceptible to disease $(\mathrm{OR}=0.43 ; 95 \% \mathrm{CI}=0.14$ to $1.35 ; \mathrm{p}=0.148)$.

The results of multiple logistic regression analysis in Table 4 showed that all independent variables had a value of -2 Likelihood $\log <100$ so that in the analysis of the model and sample data it was interpreted to be quite appropriate. The percentage of Nagelkerke $\mathrm{R}^{2}$ showed that the independent variables studied were able to explain the incidence of MR $53.8 \%$ and the other $46.2 \%$ were influenced by other factors.

\section{DISCUSSION}

\section{The relationship between maternal age and MR incidence}

Based on the results of the study, maternal age at pregnancy has a positive and significant relationship with the incidence of mental retardation. Based on the findings obtained during the study, mothers aged 35 years old and above have a higher risk of giving birth to children with mental retardation. Pregnancy in older age especially after 40 years has a worse risk. This is because at that age often accompanied by hypertension, diabetes and uterine myoma. The incidence of congenital anomalies is also increasing, generally Down Syndrome (Irianto, 2014).

The results of this study was in accordance with Huang et al. (2016) that the maternal age at pregnancy of $\geq 35$ years had a positive or more at risk of childbirth with mental retardation $(\mathrm{OR}=1.53 ; 95 \% \mathrm{CI}=1.35$ to $1.72 \mathrm{p}<0.001$ ). This was related to hormonal changes that could cause non disjunction or failure of division on chromosome 21, although no one knew for sure why MR occurred in mothers aged $\geq 35$ years at pregnancy and there was no way to prevent chromosomal errors that caused mental retardation. Scientists knew that the mothers would have a higher risk of giving birth to children with mental retardation.

\section{The relationship between socio- economic with MR incidence}

Low socioeconomic will increase the incidence of mental retardation. Education is a 
process of changing attitudes and behavior of a person or group that in an effort to mature humans through guidance, teaching and training for future roles (RI Law No. 20, 2013). Higher education level would make it easier for a person to find and receive information. The more knowledge would certainly get a better job and income. This theory was in accordance with a study conducted by Hunter et al. (2013) in the USA, which stated that low socioeconomic (low education and low wages $<\$ 25,000$ ) will increase the incidence of Down Syndrome 2.17 times. Down syndrome is the most common cause of mental retardation.

Low socioeconomic plays an important role in the survival of premature babies, children who experience congenital or acquired growth and development disorders after birth. An infant born $<28$ weeks of gestation of a parent with low socioeconomic will experience death 90\% compared with premature infants from families with high socioeconomic 10\% (Rogers and Hintz, 2016).

\section{Analyzing the relationship of envi- ronmental factors with MR incidence}

A risky environment would increase the incidence of mental retardation higher than an environment that was not at risk. The results of this study was in accordance with a study in Brazil conducted by Karam et al., (2016) that mental retardation was caused by environment (44.4\%), genetic (20.5\%), idiopathic (12.6\%), and other diseases (9.3\%). It meant that $40 \%$ of children with mental retardation were caused by nonbiological factors, and this indicated that the incidence of mental retardation could be suppressed or reduced by appropriate interventions in early life.

The environment is divided into 3 major groups, namely physical, biological and mental environment. The three large groups that are divided into the environment cannot be separated because it is a unity and can interact and influence each other. Living things are formed by the surrounding environment and can change to respond to the environmental changes that occur around it (Sembel and Tje, 2015). The environment functions as a provider of children's basic needs to grow and develop (UNICEF, 2013) and the environment influences the intellectual disability or mental retardation (Reichenberg et al., 2015). Children who live at home with lead containing paint $(\mathrm{Pb})$ are at risk of poisoning $(\mathrm{Pb})$ and result in intellectual disability (Irianto, 2014).

The right intervention at the beginning of life as stated by Karam et al., (2016) was very appropriate. Fulfillment of good nutritional needs in the family was very important, besides providing complete immunization, exclusive breastfeeding for babies, regularity of parents to come to the health center to strimulate and monitor child development, good hygiene and sanitation in the family, physical fitness and recreation were efforts made as early intervention to become human beings who are physically and mentally healthy, thus avoiding the occurrence of mental retardation.

\section{Analyze the relationship of prenat- al history to MR incidence}

Prenatal history that is at risk will increase the incidence of mental retardation higher compared with prenatal history of mothers who are not at risk. Antenatal care is carried out with the aim of monitoring pregnant women so that they are truly physically and mentally prepared, and saving mothers and children during pregnancy, childbirth and postpartum, so that their postpartum is 
healthy and normal, both physically and mentally (Irianto, 2014).

Appropriate neonatal visits are 4 times during pregnancy that is 1 time in the first trimester, 1 time in the second trimester, and 2 times in the third trimester. It will reduce the incidence of MR, because early problems can be detected in pregnant women and can be properly handled immediately. Fetal development is very susceptible to damage, especially in the first few months of its development. The consumption of drugs, alcohol or smoking is one of the factors that cause bad effects on infant development (Huang et al., 2016).

\section{Analyzing the relationship of peri- natal history with MR incidence}

The perinatal history was associated with an MR incidence. Children who were born from a mother with a poor or risky perinatal history would increase the incidence of mental retardation. The perinatal period is a period of 28 weeks pregnancy to 7 days after birth. There were so many important moments that occurred in the perinatal period if the mother had a dangerous problem in the perinatal period that could endanger the health of the mother and fetus that were still in the womb.

Childbirth and perinatal have almost the same meaning that is the process of delivery the fetus that occurs in a term pregnancy (37-42 weeks), spontaneous birth with a percentage of the back of the head that lasts for 18 hours, without complications in both the mother and fetus. Expectations of mothers, families and health workers who provide assistance in childbirth hoped this period can be passed by all mothers properly and safely, do not experience interference. However, in reality there were several women who experience difficulties in childbirth due to one or several disturbances in power (power), passenger (fetus and placenta), passage (birth canal), psychological (mother and helper), helper (health worker trained), whose consequences could interfere with the growth and development of newborns and the worst could cause mental retardation.

Babies born prematurely before 27 weeks of gestation will increase the incidence of mental retardation. Children with prematurity must have less than normal weight or called LBW. Other study explained that mental retardation can be caused by infants with LBW, neonatal asphyxia, and seizures. The prevalence of LBW is estimated to be $15 \%$ of all births in the world with a limit of 3.3 to $38 \%$ and are more common in developing or low socio-economic countries. The most common causes of LBW are premature birth, maternal age at pregnancy, parity, fetal factors such as hydramnios, gemelli, chromosomal abnormalities (Irianto, 2014). Other study say that perinatal period hypoxia is the most common cause of cognitive impairment or mental retardation (Cabarcas et al., 2013).

\section{Analyze the relationship between postnatal history and the incidence of MR}

Postnatal history that is at risk will increase the incidence of mental retardation; the relationship in influencing the incidence of mental retardation is in the moderate lower category compared to maternal age, socioeconomic and prenatal history. Postnatal is the period after delivery that is needed for recovery of the uterus for 6 weeks (Irianto, 2014). Growth is a major change in number and size at the level of cells, organs and individuals. Early childhood is a critical period in child development.

Children's intelligence development takes place very rapidly in the early years of their lives. About $50 \%$ of an adult intelli- 
gence capacity is obtained when a child is 4 years old, $80 \%$ is obtained when a child is around 18 years old (Susilaningrum et al., 2013; Nugroho, 2009).

Factors that affect mental retardation include trauma to the head, as the baby falls, infection of the brain, e.g. by cerebral meningitis, measles, tropical malaria, lack of nutrition (Kartono, 2007).

Postnatal history is a series of life events of a child after childbirth. A healthy child physically, mentally and spiritually is influenced by many things, ie from the beginning before the mother was pregnant, maternal physical, socioeconomic and environmental readiness will influence how the child will be born. If from the beginning, the mother has an unfavorable condition, for example the age of the mother who is too old, supported by a low socioeconomic and physical, mental, and social environment that is not good then in the process of pregnancy until postnatal will have a negative impact on children. In lifelong epidemiology, it has been shown that early life impacts will result in future life, and this poor or risky postnatal condition, as a continuation of a poor medical history in the past.

\section{The relationship of maternal age, socioeconomic, gestational, envi- ronmental factors, and the inci- dence of mental retardation}

Maternal age at pregnancy is the highest risk factor affecting the incidence of mental retardation, followed by environmental factors, socioeconomic factors, prenatal history, postnatal, and finally the perinatal history. Age is very influential in the reproductive process. The age that is considered optimal for pregnancy is between 20 to 30 years, whereas what is considered dangerous is pregnancy at the age of 35 years and over. Difficulties that occur in older women pregnancy are mothers often accompanied by comorbidities such as hypertension, diabetes, uterine myoma and decreased reproductive function. The conclusion of this study is that there is a relationship between maternal age at pregnancy, socioeconomic, environmental, prenatal, perinatal and postnatal history with the incidence of mental retardation.

\section{REFERENCES}

Azwar S (2012). Reliabilitas dan Validitas, Edisi 4. Yogyakarta: Pustaka Pelajar.

Amsyari, Fuad (1989). Radiasi dosis rendah dan pengaruhnya terhadap kesehatan. Surabaya: Airlangga Universitas Press. Arlington, American Psychiatric Association (2013). Diagnostic and Statistical Manual Of Mental Disorder. Fifth Edition.

AAIDD (2010).www.aamr.org diakses pada 30 Maret 2016.

Al-Amri A, Saegh AA, Al-Mamari W, El-Asrag ME, Ivorra JL, Cardno AG, Inglehearn CF (2016). Homozygous single base deletion in TUSC3 cause intellectual disability with developmental delay in Omanii family. Am J Med Genet A. PubMed.

Budiyono (2015).Pengantar Metode Statistika Multivariat. Jawa Tengah: UNS Press.

Balasubramanian, Meena, Sithambaram, Sivagamy, Smith, Kath (2016). Inhereted duplication of the short arm of chromosome 18 p11.32-p11.31 associated with developmental delay / intellectual disability. Clinical Dysmorphology. 25(1):19-22.

Bittles, Black (2010). Consanguineous Marriage and Human Evolution. Annual Review of Anthropology 39(1): 193207. 
Chentouf A, Talhi R, Dahdouh A, Benbihi L, Benilha S, Oubaiche M, Chaouch M (2015). Consanguinity and epilepsy in Oran, Algeria: A case - control study. Elseiver.0920211, www.doi.org.

Cabarcas, Espinosa, Velasco (2013). Etiologia del retardo mental en la infancia: experiencia en dos centros de tercer nivel. Biomedica. 33:402-20.

Dalyono (2010). Psikologi Pendidikan. Jakarta: Rineka Cipta.

Dwi R, Diah E, Oky P (2016). Identifikasi penyebab retardasi mental siswa slb melalui analisis sitogenetik dan PCR. Jurnal Kedokteran Brawijaya.19(1).

Dalami E, Suliswati, Rochimah, Suryati KR, Lestari W (2013). Asuhan Keperawatan Klien Dengan Gangguan Jiwa, Trans Info Medika Jaya, Jakarta.

Departemen Kesehatan RI (2012). Stimulasi, Deteksi dan Intervensi Dini Tumbuh Kembang Anak Ditingkat Pelayanan Kesehatan Dasar. Jakarta.

Herdiana (2014).Penilaian/Asesment di TK. Hamamy (2012). Consanguineous marriages. Preconception consultation in primary health care settings. Journal of Community Genetics. 3(3):185-192.

Hamamy H, Antonarakis SE, Cavalli SLL, Temtamy S, Romeo G, Ten Kate LP (2011). Consanguineous marriages, pearls and perils: Genewa International Consaguinity Workshop Report. Genet.Med.13. 841-847.

Harnilawati (2013).Konsep dan Proses Keperawatan Keluarga. Sulawesi Selatan, Pustaka As Salam.

Huang J, Zhu T, Qu Y, Mu D (2016). Prenatal, Perinatal and Neonatal Risk Faktors for Intellectual Disability: A Systemic Review and Meta-Analysis. Plos One. 11(4):e0153655.

Hunter (2013). The association of low socioeconomic status and the risk of having a child with Down syndrome: a report from the National Down Syndrome Project. NIH Public Access. 15(9);698705 .

Iqbal, Bokhoven H (2014). Identifying Genes Responsible for Intellectual Disability in Consanguineous Families'.Human Heredity. (77);150-160.

Irianto (2014). Biologi Reproduksi. Bandung, Alfabeta.

Kementerian Kesehatan (2013), Riset Kesehatan Dasar, Jakarta, Kementerian Kesehatan Republik Indonesia.

Kartono (2007). Psikologi Anak. Bandung. CV. Mandar Maju.

Keputusan Menteri Tenaga Kerja Dan Transmigrasi Republik Indonesia, Nomor: KEP.235 /MEN /2003 Tentang Jenis-jenis Pekerjaan Yang Membahayakan Kesehatan, Keselamatan Atau Moral Anak.

Karam SM, Barros AJ, Matijasevich A, Dos Santos IS, Anselmi L, Barros F, Leistner-Segal S (2016). Intellectual Disability in a Birth Cohort: Prevalensi, Etiology, and Determinants at the Age of 4 Years, Public Health Genomics. 19(5): 290-297.

Lapau (2013). Metode Penelitian Kesehatan, Metode Ilmiah Penulisan Skripsi, Tesis, dan Disertasi. Jakarta: Yayasan Pustaka Obor Indonesia.

Langridge A, Glasson E, Nassar N, Jacoby P, Pennell C, Hagan R, Bourke J, Leonard H, Stanley F 2013. Maternal Conditions and Perinatal Characteristics Associated with Autism Spectrum Disorder and Intellectual Disability. PlosONE. 8(1): e50963.

Lusiana N, Andriyani, Megasari M (2015). Buku Ajar Metodologi Penelitian Kebidanan.Yogyakarta.

Laurent O, Hu J, Kleeman MJ, Bartell SM, Cockburn M, Escobedo $\mathrm{L}$ and $\mathrm{Wu} \mathrm{J}$ 
(2016). Low birth weight and air pollution in California: Which sources and components drive the risk?. Jurnal Environment International. (7):92-93.

Latipah (2010). Strategi Self Regulated Learning dan Prestasi Belajar: Kajian Meta Analisis. Jurnal Psikologi. 37(1): 110-129.

Murti (2013). Desain dan Ukuran sampel untuk Penelitian Kuantitatif dan Kualitatif di Bidang Kesehatan. Yogyakarta: Gajah Mada University Press.

Maulik, Darmstadt (2007). Childhood Disability in Low and Middle-Income Countries: Overview of Screening, Prevention, Services, Legislation, and Epidemiology, Pediatrics. 120:S1-55.

Mangunsong (2009). Psikologi dan pendidikan anak berkebutuhan khusus. Jilid Kesatu. Depok: LPSP3 Fakultas Psikologi UI.

Mangunsong (2011). Psikologi dan pendidikan anak berkebutuhan khusus. Jilid Kedua. Depok: LPSP3 Fakultas Psikologi UI.

Muhidin, Abdurahman (2011). Analisis Korelasi, Regresi, Dan Jalur Dalam Penelitian, Bandung: CV Pustaka Setia.

Nugroho (2009). Denver Developmental Screening Test. Jakarta: EGC.

Nisbett R, Blair C, Dickens W, Flynn J, Halper D, Turkheimer E (2012). 'Intelligence: New Findings and Theoretical Developments. American Psychologist. 67(2): 130-159.

Peraturan Gubernur No. 78.(2015). Tentang Upah Minimum Kabupaten/Kota, Provinsi Jawa Timur.

Quadratullah (2014). Statistika Terapan: Teori, Contoh Kasus, dan Aplikasinya dengan SPSS/Ed.1. Yogyakarta: ANDI. Reksoprayitno (2009). Ekonomi Makro. Badan Penerbit Fakultas Ekonomi (BPFE): UGM.
Rzhetsky A, Bagley S, Wang K, Lyttle C, Cook E, Altman R, Gibbons R (2014). Environmental and State-Level Regulatory Factors Affect the Incidence of Autism and Intellectual Disability.PloS Comput. 10(3):e1003518.

Rogers, Hintz (2016). Early neurodevelopmental outcomes of extremely preterm infants. Elsevier. Seminar in Perinatology. 40(8);497-509.

Reinchenberg A, Cederlof M, McMillan A, Trzaskowski M, Kapara O, Fruchter E, Ginat K, Davidson M (2015). Discontinuity in the genetic and environmental causes of the intellectual disability spectrum. 113(4); 1098-1103.

Rai D, Lewis G, Lundberg M, Araya R, Svensson A, Dalman C, Carpenter P (2012). Parental socioeconomic status and risk of offspring autism spectrum disorders in a Swedish population-based study. Journal of the American Academy of Child \& Adolescent Psychiatry. 51(5): 467-476.e6.

Sembel, Dantje (2015). Toksikologi Lingkungan: Dampak Pencemaran dari Berbagai Bahan Kimia dalam Kehidupan Sehari - hari. Yogyakarta.

Supariasa IDN, Bakri B, Fajar I (2012). Penilaian Status Gizi. Jakarta, EGC.

Susilaningrum R, Nursalam, Utami S (2013). Asuhan Keperawatan Bayi dan Anak untuk Perawat dan Bidan. Jakarta: Salemba Medika.

Saad HA, Elbedour S, Hallaq E, Merrick J, Tenenbaum A (2014). Consanguineous marriage and intellectual and developmental disabilities among Arab Bedouins children of the Negev region in Southern Israel: a pilot study.

Sujarweni (2012). SPSS Untuk Paramedis. Yogyakarta: Gava Medika. 
Journal of Maternal and Child Health (2016), 1(2): 119-130

https://doi.org/10.26911/thejmch.2016.01.02.02

UNICEF (2008). Monitoring Child Disability in Developing Countries. New York.
UNICEF (2013). Anak Penyandang Disabilitas. www.unicef.org diakses pada 29 Maret 2016.

UU Republik Indonesia Nomor 20 Tahun 2013. Sistem Pendidikan Nasional. 